\title{
ArcheoSciences
}

Revue d'archéométrie

41-1 | 2017

Varia

\section{Determination of the chemical composition of medieval glazed pottery from Drastar (Bulgaria) using PIXE/PIGE and LA-ICP-MS}

Composition chimique de poterie glaçurée medievale de Drastar

(Bulgarie) déterminée par PIXE-PIGE et LA-ICP-MS

Valentina Lyubomirova, Žiga Šmit, Helena Fajfar and Ivelin Kuleff

\section{OpenEdition}

Journals

Electronic version

URL: https://journals.openedition.org/archeosciences/4894

DOI: $10.4000 /$ archeosciences. 4894

ISSN: 2104-3728

Publisher

Presses universitaires de Rennes

Printed version

Date of publication: 21 June 2017

Number of pages: $69-82$

ISBN: 978-2-7535-5890-8

ISSN: $1960-1360$

\section{Electronic reference}

Valentina Lyubomirova, Žiga Šmit, Helena Fajfar and Ivelin Kuleff, "Determination of the chemical composition of medieval glazed pottery from Drastar (Bulgaria) using PIXE/PIGE and LA-ICP-MS", ArcheoSciences [Online], 41-1 | 2017, Online since 21 June 2019, connection on 28 January 2022. URL: http://journals.openedition.org/archeosciences/4894; DOI: https://doi.org/10.4000/archeosciences. 4894 


\title{
Determination of the Chemical Composition of Medieval Glazed Pottery from Drastar (Bulgaria) Using PIXE/PIGE and LA-ICP-MS
}

\author{
Composition chimique de poterie glaçurée médiévale de Drastar (Bulgarie) \\ déterminée par PIXE-PIGE et LA-ICP-MS
}

\author{
Valentina Lyubomirova $^{a}$, Žiga Šmit ${ }^{\text {b, c }}$, Helena Fajfar ${ }^{b}$ and Ivelin KulefF ${ }^{a}$
}

\begin{abstract}
Fifteen samples of medieval glazed pottery from Drastar (present day Silistra), Bulgaria, dated between $10^{\text {th }}$ and $18^{\text {th }}$ centuries AD were studied. The element concentration of the glazes was determined by Proton Induced X-ray Emission (PIXE) and Proton Induced Gamma Emission (PIGE) analysis. The composition of the clay bodies was studied by Laser Ablation Inductively Coupled Plasma Mass Spectrometry (LA-ICP-MS) after pelletization of the powdered clay. In addition, Scanning Electron Microscopy with Energy Dispersive X-ray Spectroscopy (SEM-EDX) was used for characterization of the clay bodies.

After subtraction of the $\mathrm{PbO}$ and $\mathrm{CuO}$ content, the comparison between the compositions of the clay bodies and the glazes revealed that both the calcareous and the non-calcareous samples were glazed using a lead oxide based preparation followed by firing in oxidizing atmosphere. Furthermore, it was shown that iron, copper and manganese oxides were used to achieve the desired colors.

Résumé : Quinze échantillons de céramiques glaçurées médiévales de Drastar (aujourd'hui Silistra), en Bulgarie, datés entre les Xe et XVIII siècles après J.-C. ont été étudiés. Les compositions élémentaires des glaçures ont été déterminées par les méthodes analytiques : émission de rayons $X$ induite par protons (PIXE) et émission de rayons gamma induite par protons (PIGE). La composition de la matrice argileuse a été étudiée par spectrométrie de masse á plasma inductif avec ablation laser (LA-ICP-MS) sur pastilles des poudres d'argiles. En complément, la microscopie électronique à balayage couplée á la spectroscopie $X$ en dispersion d'énergie (SEM-EDX) a été aussi utilisée pour la caractérisation des matrices argileuses.

Après soustraction des teneurs en $\mathrm{PbO}$ et $\mathrm{CuO}$, la comparaison entre les compositions des matrices et celles des glaçures a révélé que tous les échantillons (pâtes calcaires et non calcaires) ont été glaçurés en utilisant de l'oxyde de plomb suivi d'une cuisson en atmosphère oxydante. De plus, il a été montré que le fer, le cuivre et les oxydes de manganèse ont été utilisés pour obtenir les couleurs souhaitées.
\end{abstract}

Keywords: Medieval glazed pottery, Bulgaria, Drastar, PIXE-PIGE, LA-ICP-MS.

Mots clés : Céramiques médiévales glaçurées, Bulgarie, Drastar, PIXE-PIGE, LA-ICP-MS.

${ }^{a}$ Faculty of Chemistry and Pharmacy, University of Sofia, James Bourchier 1, 1164-Sofia, Bulgaria. (vlah@chem.uni-sofia.bg)

${ }^{b}$ Faculty of Mathematics and Physics, University of Ljubljana, 19, Jadranska Str., SI-1000 Ljublana, Slovenia.

'Jožef Stefan Institute, 39, Jamova Str., SI-1000 Ljublana, Slovenia. 


\section{INTRODUCTION}

From the $4^{\text {th }}$ millennium BC onwards in the Near East region and Egypt alkali glazes were used first for covering steatite and ground quartz vessels (i.e. Egyptian faience) and then clay vessels from the $15^{\text {th }}$ century BC (Tite et al., 1998).

The earliest known lead glazed ceramics in the West were produced during the Roman era (about $1^{\text {st }}$ century BC) (Tite et al., 1998; Wolf et al., 2003; Walton and Tite, 2010) after their appearance in China perhaps a few centuries earlier (Tite et al., 1998).

Evidence of the production of these wares comes from several sites in Anatolia (present-day Turkey) (Walton and Tite, 2010). Subsequently, glazes of this type were extensively used for pottery and tiles throughout the Islamic and Byzantine world and medieval Europe (Wolf et al., 2003). At present their use is continuing in the Near East and Europe (Tite et al., 1998; Wolf et al., 2003). From the late $12^{\text {th }}$ century AD, the high lead glaze type was also used in China as the basis for colored overglaze enamels (Tite et al., 1998).

An important category of glazed pottery, first produced in Iraq in the $8^{\text {th }}$ century $\mathrm{AD}$ is the tin-opacified glazes, initially containing up to $1-2 \% \mathrm{PbO}$ (Charalambous et al., 2010). Gradually the percentage of $\mathrm{PbO}$ increased and by the $10^{\text {th }}$ $11^{\text {th }}$ century AD the glazes typically contained $20-40 \%$ $\mathrm{PbO}$ and $5-12 \%$ alkali (Wolf et al., 2003). According to Davis and Stocker (2013) typical concentration of $\mathrm{SnO}_{2}$ in tin-opacified glazes amounts to 4-9 wt.\% Thereafter, the produced tin-opacified glazes throughout the Near East and Europe are characterized by this composition.

The reasons for replacement of the alkali glazes with lead glazes are lower melting temperature, higher fluidity and thus better coating the glazed surfaces. In addition lower thermal expansion which predetermines lower risk of glaze crazing and higher refractive index leading to greater brilliance (Wolf et al., 2003) are factors that led to the widespread use of high-lead and lead-alkali glazes.

There are mainly two ways to produce high lead glazes. The first one is to use a lead compound, such as litharge $(\mathrm{PbO})$, red lead $\left(\mathrm{Pb}_{3} \mathrm{O}_{4}\right)$, white lead $\left(2 \mathrm{PbCO}_{3} \cdot \mathrm{Pb}(\mathrm{OH})_{2}\right)$ or galena $(\mathrm{PbS})$. In the second way, a suspension of a lead compound with silica in the form of quartz sand, ground quartz or chert pebbles is used. In both methods, a small amount of clay, gum or starch can be added to the glaze slurry to maintain the lead and silica particles in suspension. The application can be to either unfired or biscuit fired bodies (Tite et al., 1998). The lead oxide-plus-quartz suspension can be applied either in a raw state or after pre-fritting (Walton and Tite, 2010).
The lead glazes are easily formed, obtain lustrousness and opacity at low temperature and are also easily colored with oxides of other metals (Charalambous et al., 2010). Apart from the concentration, the oxidation states of copper and iron are also important for obtaining a particular color. The green color is traditionally related to the presence of $\mathrm{Cu}^{2+}$ (Davis and Stocker, 2013) or $\mathrm{Fe}^{2+}$ (De Benedeto et al., 2004; Molera et al., 1997; Wakamatsu et al., 1987). If no copper has been detected in the glazes, the change of the color must be related to the degree of oxidation of the iron (Molera et al., 1997; Wakamatsu et al., 1987). $\mathrm{Fe}^{3+}$ is responsible for the brown, yellow, black and red colors (Molera et al., 1997), however, black glazes also have $\mathrm{Mn}$ and yellow glazes also contain $\mathrm{Cr}$ (Charalambous et al., 2010). Co-based pigments were well known for the blue color (Wolf et al., 2003) due to $\mathrm{CoO}_{4}$ complex (Charalambous et al., 2010) or probably Co-Ni-minerals (Kleinmann, 1991).

The production of lead glazes expanded rapidly, attributed to the growing Roman markets and since the $7^{\text {th }}$ century $\mathrm{AD}$ lead glazes were produced also in the Balkans (Walton and Tite, 2010).

The production of glazed pottery in Bulgaria is about $2 \%$ of the pottery in general. Glazed pottery has been found during archaeological excavations in Drastar and the nearness (Koleva, 2008; Mancheva, 1986), Karaachteke near Varna (Yoleva et al., 2015), Zlatna Livada, near Chirpan (Koleva, 2015), Pliska (Djingova and Kuleff, 1992), etc. Fragments of glazed ceramic vessels although not many, are always part of the ceramic finds from the Early Medieval pits and houses, which lay above or are dug into the Late Antiquity stratigraphic layer. Its fragmentation is a result of the representative character of this valuable ceramics and the fact that its quantity was considerable less in comparison to the other vessels. The fragments allow identifying the major shapes of vessels, which are very diverse - pitchers, handles, dishes, vessels, etc [Koleva, 2009].

Glazed pottery from Bulgaria has not attracted much interest in terms of analytical studies. The subjects of the present investigation are fifteen medieval glazed pottery vessels. The samples are taken from town Drastar (present day Silistra) (see Fig. 1) where in the recent years medieval kilns for pottery production were discovered during archaeological excavations (Angelova and Koleva, 2005; Koleva, 2008). The excavated kilns are evidence for the production of sgraffito pottery in Drastar in the period from $13^{\text {th }}$ to $14^{\text {th }}$ century AD [Koleva, 2008]. A detailed description of the town Drastar can be found in Angelova (1988).

The aims of the present paper are to determine: (i) the chemical composition of the pottery; (ii) the type of colo- 


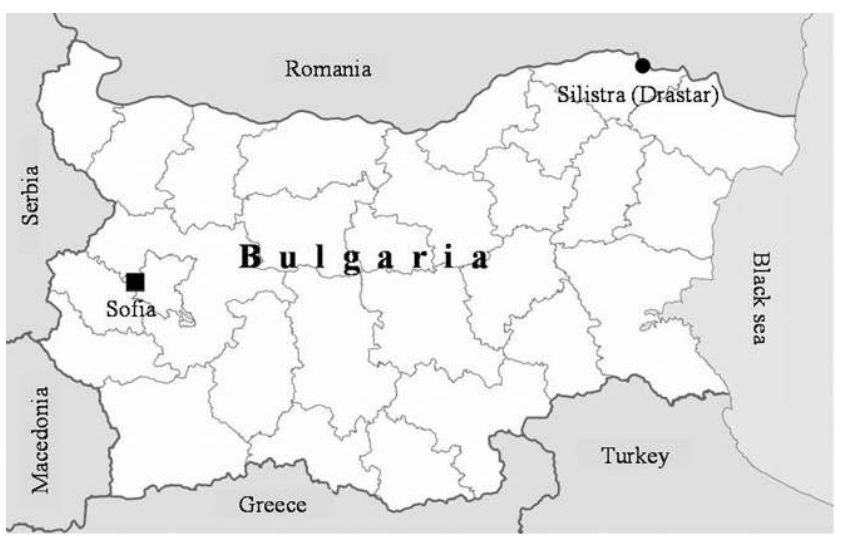

Figure 1: Map of Bulgaria with the location of Silistra. Figure 1: Carte de la Bulgarie avec l'emplacement géographique de Silistra.

rants in the glazes after chemical characterization of the glaze; (iii) the technology of production of high lead glazes from Drastar.

\section{Materials andS Methods}

\section{Materials}

In the the present investigation fifteen glazed pottery fragments from Drastar were analyzed. Four of the samples (Nrs. from 1 to 4 ) were found in the room leading to the uncovered kiln. This fact is a further evidence for the existence of medieval kilns for pottery production in the city, as already established by Koleva, 2008.

The rest of the samples (Nrs. from 5 to 15) were found during excavations of part of the medieval site of Drastar. Two of the samples (Gl-P-10 and Gl-P-11) are probably imported from Byzantium.

The investigated samples are only fragments (not entire objects) of sgraffito and glazed ceramics which represent parts mainly from vessels and dishes - bottom, edge and side part and one handle. Most of the samples are glazed from one side and two of them are glazed from both sides. The glazes have different color, dominated by green, brown and yellow in different shades laid on a red, grey or white clay.

A short description of the pottery samples is given in Table 1. Pictures of the samples with numbers from $\mathrm{Nr}$.

\begin{tabular}{|c|c|}
\hline Lab. code & Description \\
\hline Gl-P-1 & $\begin{array}{l}\text { sgraffito pottery, } 13^{\text {th }} \text { cent. } \mathrm{AD} \text {, lead glaze before firing with white-yellowish color, the find was discovered in the room which } \\
\text { leaded to the kiln }\end{array}$ \\
\hline Gl-P-2 & $\begin{array}{l}\text { sgraffito pottery, } 13^{\text {th }} \text { cent. } \mathrm{AD} \text {, lead glaze before firing with white-yellowish color, the find was discovered in the room which } \\
\text { leaded to the kiln }\end{array}$ \\
\hline Gl-P-3 & $\begin{array}{l}\text { sgraffito pottery, } 13^{\text {th }} \text { cent. } \mathrm{AD} \text {, lead glaze before firing with white-yellowish color, the find was discovered in the room which } \\
\text { leaded to the kiln }\end{array}$ \\
\hline Gl-P-4 & $\begin{array}{l}\text { sgraffito pottery, } 13^{\text {th }} \text { cent. } \mathrm{AD} \text {, lead glaze before firing with white-yellowish color, the find was discovered in the room which } \\
\text { leaded to the kiln }\end{array}$ \\
\hline Gl-P-5 & sgraffito pottery; $13^{\text {th }}$ cent. $\mathrm{AD}$, bottom of vessel, red clay \\
\hline Gl-P-6 & sgraffito pottery, $13^{\text {th }}$ cent. $\mathrm{AD}$, bottom of vessel, red clay \\
\hline Gl-P-7 & glazed pottery, $16^{\text {th }}$ cent. $\mathrm{AD}$, edge of vessel, red clay \\
\hline Gl-P-8 & glazed pottery, $11^{\text {th }}$ cent. $\mathrm{AD}$, handle, grey clay \\
\hline Gl-P-9 & glazed pottery, $13^{\text {th }}$ to $14^{\text {th }}$ cent. $\mathrm{AD}$, bottom of vessel, glazed from both sides, white clay \\
\hline Gl-P-10 & glazed pottery, $10^{\text {th }}$ cent. AD, bottom of vessel, glazed from both sides, white clay, probably imported from Byzantium \\
\hline Gl-P-11 & sgraffito pottery, $10^{\text {th }}$ to $12^{\text {th }}$ cent. $\mathrm{AD}$, bottom of vessel, white clay, probably imported from Byzantium \\
\hline Gl-P-12 & glazed pottery, $18^{\text {th }}$ cent. $\mathrm{AD}$, side part of vessel, red clay \\
\hline Gl-P-13 & sgraffito potery, $16^{\text {th }}$ cent. $\mathrm{AD}$, side part of dish; red clay \\
\hline Gl-P-14 & sgraffito potery, $13^{\text {th }}$ cent. $\mathrm{AD}$, bottom of vessel, red clay \\
\hline Gl-P-15 & sgraffito potery, $14^{\text {th }}$ cent. $\mathrm{AD}$; bottom of vessel; red clay \\
\hline
\end{tabular}

Table 1: Description of the investigated glazed pottery from Drastar (present day Silistra).

Tableau 1 : Description des poteries glaçurées de Drastar (aujourd'hui Silistra) analysées. 
5 to Nr. 15 are presented in Figure 2. The samples are dated archaeologically to $10^{\text {th }}$ century $(\mathrm{Nr} .10), 11^{\text {th }}$ century (Nr. 8), $10^{\text {th }}$ to $12^{\text {th }}$ century (Nr. 11$), 13^{\text {th }}$ century (Nrs. from 1 to 6 , and 14$), 13^{\text {th }}-14^{\text {th }}$ century (Nr. 9), $14^{\text {th }}$ century (Nr. 15), 16 ${ }^{\text {th }}$ century (Nrs. 7 and 13), $18^{\text {th }}$ century (Nr. 12).

The surface of some glazes suffered severe deterioration due to environmental erosive factors as humidity and soluble salts. This effect is clearly visible on samples Gl-P10.1, Gl-P-10.2, Gl-P-11 (see Fig. 2). More information about the analyzed samples is given in Koleva, 2008 and Mancheva, 1986.

The analyzed samples are very common and typical and are chosen as representative samples for the medieval glazed pottery, excavated in the Drastar region.

\section{Analytical methods}

\section{Proton induced $X$-ray and proton induced gamma-ray emissions}

The glaze covered pottery fragments were analyzed using Proton Induced X-ray Emission (PIXE) and Proton Induced Gamma Emission (PIGE). The measurements were performed at the Tandem accelerator of the Jožef Stefan Institute in Ljubljana, Slovenia using a proton beam of $3 \mathrm{MeV}$ nominal energy in air. A combined PIXE-PIGE method was applied. The concentration of $\mathrm{Al}_{2} \mathrm{O}_{3}, \mathrm{CaO}, \mathrm{CuO}, \mathrm{Fe}_{2} \mathrm{O}_{3}, \mathrm{~K} 2 \mathrm{O}, \mathrm{MgO}$, $\mathrm{MnO}, \mathrm{Na}_{2} \mathrm{O}, \mathrm{PbO}, \mathrm{SiO}_{2}, \mathrm{Cr}_{2} \mathrm{O}_{3}$ and $\mathrm{TiO}_{2}$, was determined. Elements heavier than silicon were analysed according to their characteristic X-rays, detected by a $\mathrm{Si}(\mathrm{Li})$ detector of $160 \mathrm{eV}$ resolution at $5.89 \mathrm{keV}$. The proton energy at the target, after passing an $8 \mu \mathrm{m}$ aluminium window and a $1.1 \mathrm{~cm}$ air-gap, was $2.70 \mathrm{MeV}$. The air gap between the target and X-ray detector was $5.7 \mathrm{~cm}$, which acted as an efficient absorber of intense silicon X-rays. The beam size at the target was a few $\mathrm{mm}^{2}$. Typical measurements times were $300-500$ seconds at a proton current of $<1 \mathrm{nA}$. Sensitivity for mid-Z element was improved to about $5 \mathrm{mg} \mathrm{kg}^{-1}$ by an aluminium absorber of $0.1 \mathrm{~mm}$ thickness, and increasing the proton current to a few $\mathrm{nA}$. Spectral deconvolution was performed by the AXIL code.

The contents of $\mathrm{Na}, \mathrm{Mg}$ and $\mathrm{Al}$ were determined from the intensities of gamma rays excited by inelastic proton scattering. As the proton exit window, a $2 \mu \mathrm{m}$ thick tantalum foil on a brass nozzle was used. Gamma rays were detected by a $40 \%$ intrinsic germanium detector. The gamma lines exploited for analysis were $440 \mathrm{keV}$ for $\mathrm{Na}, 585 \mathrm{keV}$ for $\mathrm{Mg}$, and 844 and $1014 \mathrm{keV}$ for Al. Line intensities were determined by the GRILS program of the GANAAS software package. For gamma measurement, the proton current was 2-3 nA and the collected dose was about $5 \mu \mathrm{C}$ for the sample, and $15 \mu \mathrm{C}$ for the standard.

The elemental concentrations were calculated by an iterative procedure, using simultaneously both $\mathrm{X}$-ray and gamma-ray intensities. The contents of $\mathrm{Na}, \mathrm{Mg}$ and $\mathrm{Al}$ were determined within the surface approximation, using NIST SRM 610 glass standard for calibration. Periodically the NIST SRM 610 and NIST SRM 612 glass standards were measured as unknown samples. The accuracy of the method was within $5 \%$ for major elements, but decreased to $10-20 \%$ for the elements at the sub $0.1 \%$ level. Uncertainties are also large for $\mathrm{Mg}$ approaching the detection limit; at about $0.4 \%$ they may be as high as $30 \%$.

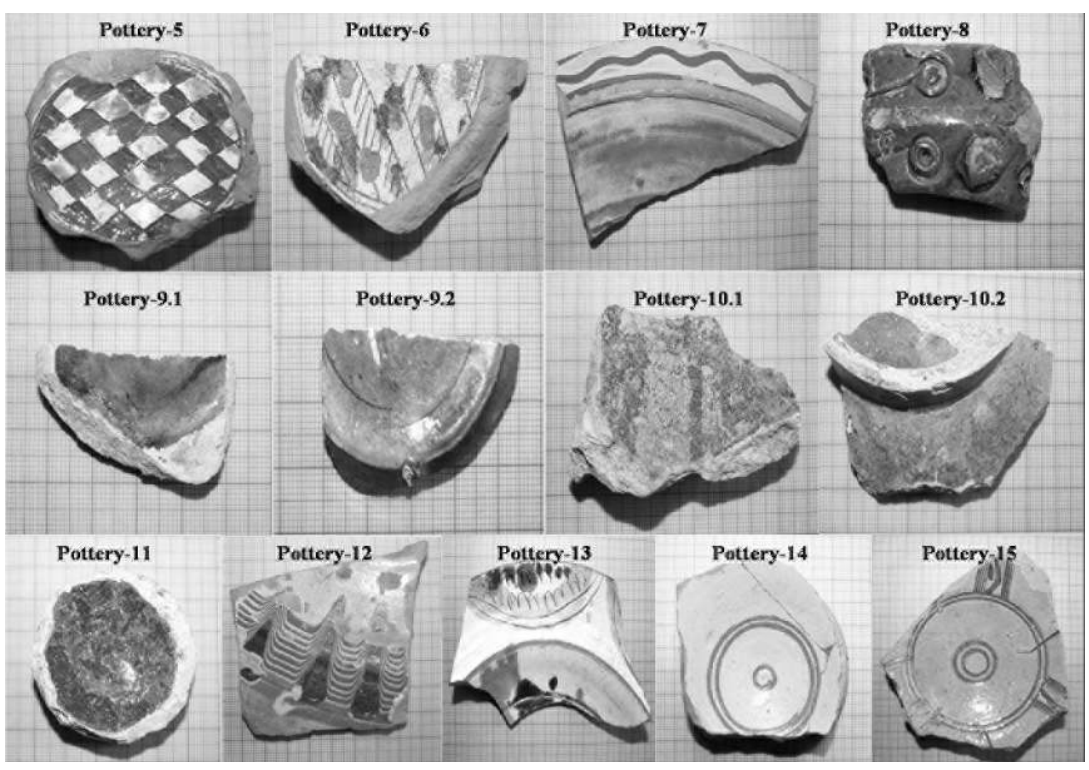

Figure 2: (See colour plate X) Pictures of some of the glazed pottery samples.

Figure 2: (Voir planches couleur X) Photos de certains des échantillons de poterie glaçurée. 


\section{Laser ablation mass spectrometry with inductively plasma}

The concentration of the elements in pottery was determined by Laser Ablation Inductively Coupled Plasma Mass Spectrometry (LA-ICP-MS). Due to the different porosity of the samples which lead to irreproducible results by direct ablation of the pottery, the samples were prepared in the form of pellets. A small part of the surface ceramic body layer was removed by a drill and a tungsten carbide cutter to eliminate possible surface contamination effects. The samples $(0.1 \mathrm{~g})$ were ground in agate mortar for $20 \mathrm{~min}$, then mixed with $\mathrm{H}_{3} \mathrm{BO}_{3}$ in ratio $1: 5$, well homogenised and ground again. Afterwards the mixture was pressed into a pellet of $1.2 \mathrm{~cm}$ diameter and $2 \mathrm{~mm}$ thickness under pressure of 2 bars for $1 \mathrm{~min}$. This approach has been developed for ED-XRF analysis of soils (Ivanova et al., 1998). The calibration of the LA-ICP-MS system was performed by the Certified Reference Material Ohio Red Clay, prepared by Harbottle (1976). Pellets of the Certified Reference Material Ohio Red Clay was prepared the same way and used for calibration of the LA-ICP-MS system. A summary of the analytical data for 42 elements obtained by analysing Ohio Red Clay from different laboratories are published in Kuleff and Djingova (1998). The published mean values of the elements of interest were used as certified values for the calibration of the LA-ICP-MS system.

The LA-ICP-MS conditions for measurement of the elements of interest are given in Table 2A (ICP-MS, Perkin Elmer SCIEX DRC-e) and 2B (LA, New Wave Research).
For the simultaneous determination of total element composition in the samples, the signal of the matrix elements was reduced by the introduction of the rejection parameter $(\mathrm{RPa})$ to enable the high-mass cut off. The optimized $\mathrm{RPa}$ values for the measured isotopes of the matrix elements are listed in Table 2.

\section{SEM-EDX microanalyses}

Scanning Electron Microscopy (SEM), (TESCAN, SEM/FIB LYRA I XMU) with Energy Dispersive X-ray Spectroscopy (EDX) (Quantax 200, Bruker) was applied used to obtain surface images of some of the glazes and potteries. Before analysis the samples were coated with graphite.

\section{RESULTS}

The analytical data for the composition of the clay bodies of the fragments, determined by LA-ICP-MS are reported in Table 3.

The data show that the ceramic pastes consist mainly of $\mathrm{SiO}_{2}(64-75 \%), \mathrm{Al}_{2} \mathrm{O}_{3}(9-17 \%), \mathrm{CaO}(1.3-18 \%), \mathrm{Fe}_{2} \mathrm{O}_{3}$ $(1.6-10 \%), \mathrm{K}_{2} \mathrm{O}(1-4 \%), \mathrm{MgO}(1-3 \%)$ and $\mathrm{Na}_{2} \mathrm{O}(0.7-$ $1.8 \%)$.

The results from the chemical analyses of the glazes (sample Nrs. from 5 to 15) are summarized in Table 4. Figure 3 presents the ternary diagram $-\mathrm{SiO}_{2}, \mathrm{PbO}$, and the sum of concentrations of $\mathrm{Na}_{2} \mathrm{O}+\mathrm{K}_{2} \mathrm{O}+\mathrm{MgO}+\mathrm{CaO}+\mathrm{Al}_{2} \mathrm{O}_{3}$. The average metal concentrations are about $46 \% \mathrm{PbO}$,

\begin{tabular}{|c|c|c|c|}
\hline \multicolumn{2}{|c|}{ A. ICP-MS } & \multicolumn{2}{|c|}{ B. LA } \\
\hline Argon plasma gas flow & $15 \mathrm{~L} \mathrm{~min}^{-1}$ & Wavelength & $213 \mathrm{~nm}$ \\
\hline Auxiliary gas flow & $1.20 \mathrm{~L} \mathrm{~min}^{-1}$ & Laser ablation chamber & $\begin{array}{c}\text { Standard } \\
\text { (New Wave Research) }\end{array}$ \\
\hline Nebulizer gas flow & $0.90 \mathrm{~L} \mathrm{~min}^{-1}$ & Ablation mode & Continuous \\
\hline Lens voltage & $6.00 \mathrm{~V}$ & Line length & $4000 \mu \mathrm{m}$ \\
\hline ICP-RF power & $1100 \mathrm{~W}$ & Pulse duration & $5 \mathrm{~ns}$ \\
\hline Pulse stage voltage & $950 \mathrm{~V}$ & Beam diameter & $100 \mu \mathrm{m}$ \\
\hline Dwell time & $50 \mathrm{~ms}$ & Fluence & $7.5 \mathrm{~J} \mathrm{~cm}^{-2}$ \\
\hline Acquisition mode & Peak hop & Repetition rate & $10 \mathrm{~Hz}$ \\
\hline Peak pattern & $\begin{array}{c}\text { One point per mass at maximum } \\
\text { peak }\end{array}$ & Scanning speed & $10 \mu \mathrm{m} \mathrm{s}^{-1}$ \\
\hline Number of runs & 4 & Carrier gas (Ar) flow rate & $1.0 \mathrm{~L} \mathrm{~min}^{-1}$ \\
\hline Determined isotopes ( $\mathrm{RPa})$ & \multicolumn{3}{|c|}{$\begin{array}{c}{ }^{23} \mathrm{Na}(0.013),{ }^{27} \mathrm{Al}(0.015),{ }^{28} \mathrm{Si}(0.016),{ }^{42} \mathrm{Ca}(0.013),{ }^{39} \mathrm{~K}(0.016),{ }^{54} \mathrm{Fe}(0.015),{ }^{56} \mathrm{Fe}(0.015),{ }^{57} \mathrm{Fe} \\
(0.013),{ }^{24} \mathrm{Mg}(0.014),{ }^{47,48,49} \mathrm{Ti},{ }^{50,52} \mathrm{Cr},{ }^{55} \mathrm{Mn},{ }^{63,65} \mathrm{Cu},{ }^{207,}, 208 \mathrm{~Pb}\end{array}$} \\
\hline
\end{tabular}

Table 2: LA-ICP-MS operation conditions for the quantitative analysis of the pottery.

Tableau 2 : Les conditions de mesure en LA-ICP-MS utilisées pour l'analyse quantitative de la céramique. 


\begin{tabular}{|c|c|c|c|c|c|c|c|c|c|c|c|c|}
\hline Sample & $\mathrm{Na}_{2} \mathrm{O}$ & $\mathrm{MgO}$ & $\mathrm{Al}_{2} \mathrm{O}_{3}$ & $\mathrm{SiO}_{2}$ & $\mathrm{~K}_{2} \mathrm{O}$ & $\mathrm{CaO}$ & $\mathrm{TiO}_{2}$ & $\mathrm{Cr}_{2} \mathrm{O}_{3}$ & $\mathrm{MnO}$ & $\mathrm{Fe}_{2} \mathrm{O}_{3}$ & $\mathrm{CuO}$ & $\mathrm{PbO}$ \\
\hline Gl-P-5 & 1.72 & 1.83 & 12.1 & 69.3 & 3.42 & 5.09 & 0.55 & 0.11 & 0.16 & 6.65 & 0.02 & $<0.001$ \\
\hline Gl-P-6 & 1.41 & 2.46 & 10.2 & 73.5 & 2.12 & 5.33 & 0.59 & 0.03 & 0.12 & 5.14 & 0.01 & 0.53 \\
\hline Gl-P-7 & 1.21 & 2.41 & 13.4 & 72.5 & 0.98 & 4.85 & 0.69 & 0.02 & 0.21 & 3.89 & 0.01 & 0.67 \\
\hline Gl-P-8 & 1.12 & 3.02 & 15.9 & 70.0 & 1.40 & 2.48 & 1.10 & 0.04 & 0.28 & 5.61 & 0.04 & $<0.001$ \\
\hline Gl-P-9 & 0.82 & 1.23 & 16.9 & 72.7 & 2.20 & 4.15 & 0.86 & 0.01 & 0.02 & 1.64 & 0.02 & 1.54 \\
\hline Gl-P-10 & 0.67 & 0.95 & 13.8 & 68.0 & 2.77 & 11.6 & 0.5 & 0.01 & 0.02 & 1.93 & 0.01 & 1.05 \\
\hline Gl-P-11 & 0.64 & 1.1 & 7.75 & 64.6 & 2.95 & 19.6 & 0.97 & 0.01 & 0.02 & 2.44 & 0.01 & $<0.001$ \\
\hline Gl-P-12 & 1.12 & 2.74 & 15.9 & 67.7 & 4.41 & 2.3 & 1.06 & 1.02 & 0.14 & 5.77 & 0.01 & 0.04 \\
\hline Gl-P-13 & 1.73 & 2.7 & 12.9 & 73.0 & 1.15 & 4.88 & 0.67 & 0.01 & 0.50 & 2.82 & 0.01 & 0.42 \\
\hline Gl-P-14 & 1.62 & 1.9 & 8.54 & 74.6 & 2.24 & 4.27 & 0.62 & 0.01 & 0.09 & 6.16 & 0.01 & $<0.001$ \\
\hline Gl-P-15 & 1.78 & 2.17 & 11.5 & 68.2 & 2.78 & 2.40 & 1.46 & 0.02 & 0.12 & 9.54 & 0.02 & 0.31 \\
\hline
\end{tabular}

Table 3: Chemical compositions of the clay boddies of samples (normalized to 100\%) using LA-ICP-MS; the number of the decimal places is related to the precision of the measurements.

Tableau 3: Compositions chimiques des pâtes des échantillons analysés (normalisées à 100\%) obtenues par LA-ICP-MS; le nombre de décimales est liée à la précision des mesures.

$39 \% \mathrm{SiO}_{2}, 7 \% \mathrm{Al}_{2} \mathrm{O}_{3}, 2 \% \mathrm{Fe}_{2} \mathrm{O}_{3}, 1 \% \mathrm{~K}_{2} \mathrm{O}, 1 \% \mathrm{MgO}$ and $\mathrm{Na}_{2} \mathrm{O}<1 \%$. The concentration of $\mathrm{CaO}$ is about $2 \%$, with the exception of Gl-P-10 and Gl-P-11, glazed over white paste, both of them dated to $10^{\text {th }}-12^{\text {th }}$ century AD and imported from Byzantium. The investigated samples could be considered as high-lead glazes although the concentrations of $\mathrm{PbO}$ are lower compared to the glaze from other sources (see e.g. Tite et al., 1998). Literature data confirm the use of lead glazes on the Balkans as early as the $7^{\text {th }}$ century AD (Walton and Tite, 2010).

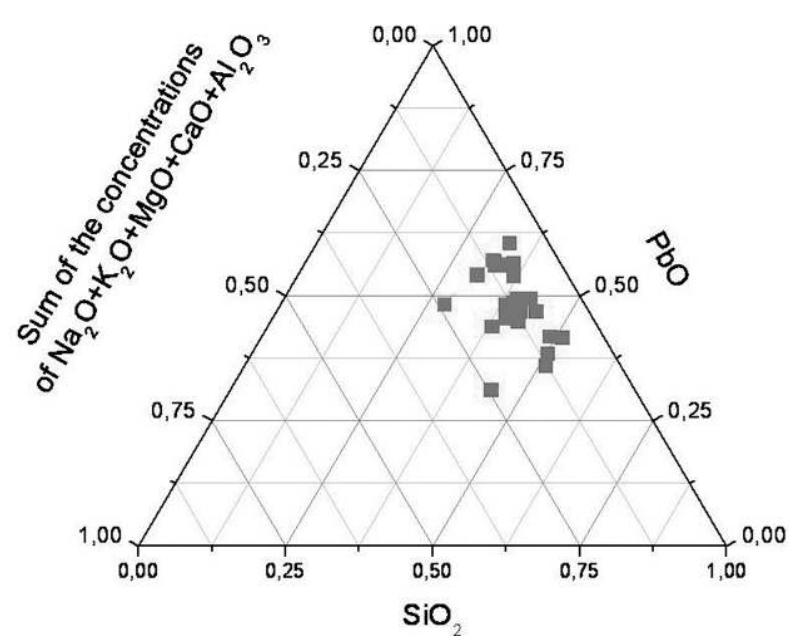

Figure 3: Ternary diagram of the concentration of $\mathrm{SiO}_{2}, \mathrm{PbO}$ and the sum of $\mathrm{Na}_{2} \mathrm{O}+\mathrm{K}_{2} \mathrm{O}+\mathrm{MgO}+\mathrm{CaO}+\mathrm{Al}_{2} \mathrm{O}_{3}$.

Figure 3 : Diagramme ternaire de la concentration de $\mathrm{SiO}_{2}, \mathrm{PbO}$ et la somme $\mathrm{Na}_{2} \mathrm{O}+\mathrm{K}_{2} \mathrm{O}+\mathrm{MgO}+\mathrm{CaO}+\mathrm{Al}_{2} \mathrm{O}_{3}$.
As discussed by Tite et al. (1998), two primary methods for production of lead glazes: either lead oxide (or some other lead compound) is applied to the surface of the pottery body, or a mixture of lead oxide and quartz. The two primary glazing methods can be distinguished by subtracting the percentage of lead oxide and any intentionally added oxide as a colorant (e.g. copper oxide) from the glaze composition and renormalizing the resulting composition to 100\% (Hurst and Freestone, 1996; Walton and Tite, 2010). The concentration of the metal oxides in the glaze composition after subtraction of percentages of $\mathrm{PbO}$ and $\mathrm{CuO}$ is presented in Table 5.

\section{Discussions}

\section{Chemical composition of the body}

Table 3 presents the results from the LA-ICP-MS analysis of the clay pellets. Based on the concentration of $\mathrm{CaO}$ clay bodies are classified in two groups. Figure 4 presents the distribution of the investigated samples (bodies and glazes) based on the concentration of $\mathrm{CaO}$ and $\mathrm{Al}_{2} \mathrm{O}_{3}$. Most of the samples dated to $10^{\text {th }}-18^{\text {th }}$ century $\mathrm{AD}$ have non-calcareous clay body $(\mathrm{CaO} \leq 5 \%)$. The samples from this group have red color due to high iron oxide concentration (3-10\%), low temperature and oxidizing atmosphere of firing. Under these conditions iron oxide, present at relatively high levels predominantly occurs in the form of hematite, which contributes to the red hue of the pottery (Molera et al., 1997). 


\section{Body}

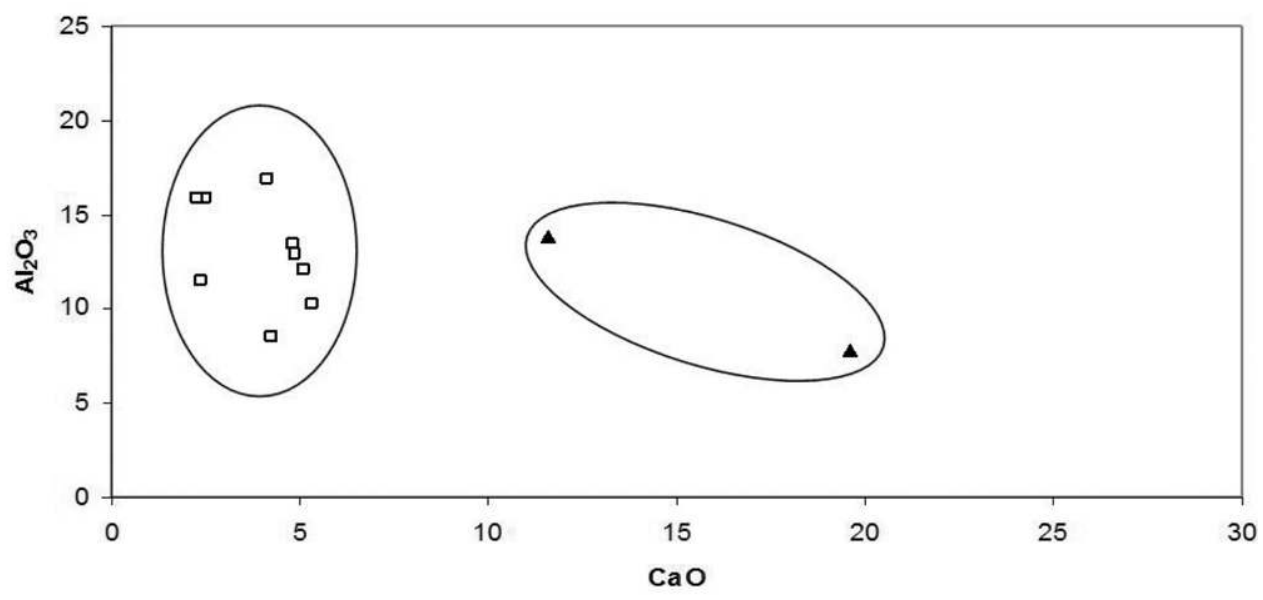

a non-calcareous $\Delta$ calcareous

\section{Glaze}

Figure 4: Distribution of the samples (bodies and glazes) according to $\mathrm{CaO}$ and $\mathrm{Al}_{2} \mathrm{O}_{3}$ concentrations.

Figure 4 : Distribution des échantillons (pâtes et glaçures) selon les concentrations de $\mathrm{CaO}$ et d'Al $\mathrm{O}_{3}$.

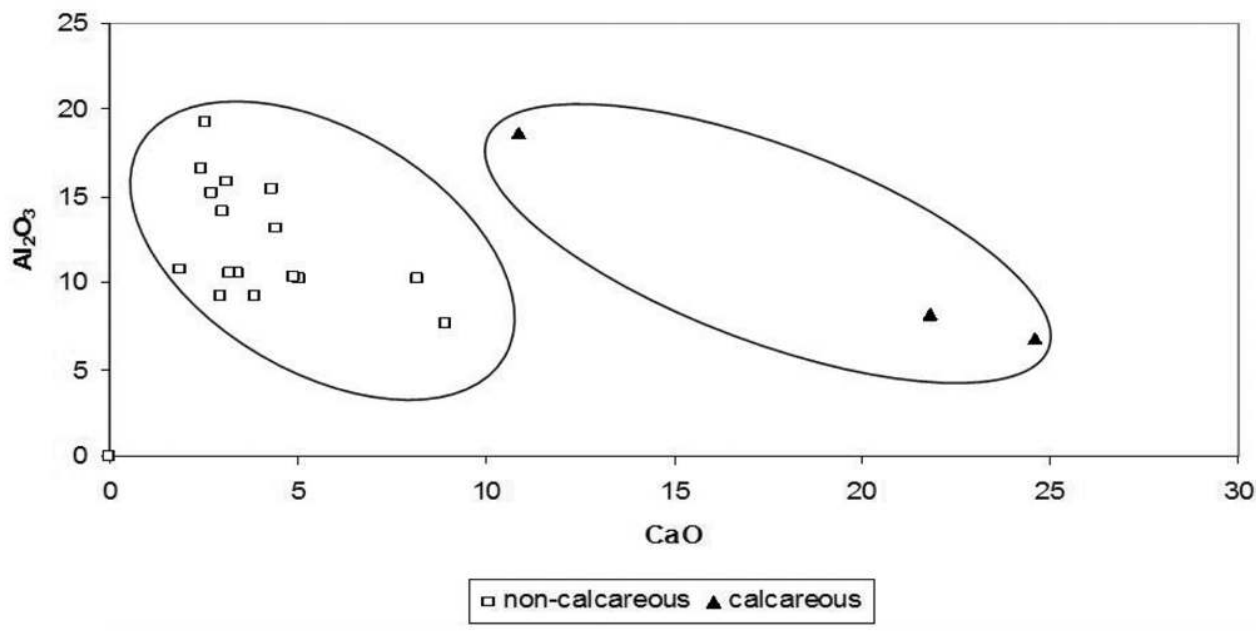

Comparison with other samples from Bulgaria is rather difficult, because of the limited number of analytical data. However, non-calcareous medieval unglazed and glazed ceramic artifacts were also discovered in other places, e.g. during archaeological excavations at the monastery of Karaachteke near Varna (Bulgaria). Both the unglazed and glazed artifacts contained a certain amount of coloring oxides $\left(\mathrm{Fe}_{2} \mathrm{O}_{3}\right.$ $+\mathrm{TiO}_{2}$ ), which determined their slightly red color (Yoleva et al., 2015).

Two of the samples from this group show different chemical composition and have grey (Gl-P-8, dated to $11^{\text {th }}$ century $\mathrm{AD}$ ) and white (Gl-P-9, dated to $13^{\text {th }}-14^{\text {th }}$ century AD) colored bodies.

Sample Gl-P-8 represents a handle and is entirely glazed. Despite the presence of high iron oxide concentration, the body of this sample has grey color. This result may be ascribed to firing in a reducing atmosphere at temperature over $850^{\circ} \mathrm{C}$ (temperature reached while reduction is performed) and the presence of well-developed hercynite and $\mathrm{Fe}^{2+}$ in the silicate phase (Molera et al., 1997). The ceramic body is brown glazed which is related to the presence of $\mathrm{Fe}^{3+}$ in oxidizing environment. The reason for this effect is that reducing atmosphere is created during the firing process by the gases produced inside the ceramic body, enclosed by glaze on all sides. During firing, reducing and inert gases such as $\mathrm{CO}$, water vapor, $\mathrm{CO}_{2}$, etc. are produced which consume oxygen inside the kiln and the pottery cannot be completely oxidized. During the cooling phase, there is no burning, and the partial pressure of oxygen is $20 \%$, and the iron of the paste is oxidized while the temperature is relatively high 
(over $500^{\circ} \mathrm{C}$ ). If all sides are glazed the ceramic body is sealed before the oxidizing atmosphere reaches the paste and, thus, it remains reduced due to the protective action of the glaze (Molera et al., 1997).

Sample Gl-P-9 is characterized by lower $\mathrm{Na}_{2} \mathrm{O}, \mathrm{MgO}$ and $\mathrm{Fe}_{2} \mathrm{O}_{3}$ and higher $\mathrm{PbO}$ concentrations. Since the sample is glazed on both sides, the white color of the body can be also related to a reducing atmosphere during the firing process. It is also possible that the high $\mathrm{CaO}$ content (three times higher than $\mathrm{Fe}_{2} \mathrm{O}_{3}$ ) may contribute to the white color of the body.

The results show that two of the samples (Gl-P-10 and Gl-P-11) which are dated from $10^{\text {th }}$ to $12^{\text {th }}$ century $A D$ and imported to medieval Bulgaria from Byzantium have white colored calcareous clay bodies. They are characterized by high $\mathrm{CaO}(>10 \%)$ and low $\mathrm{MgO}(-1 \%), \mathrm{Na}_{2} \mathrm{O}(>1 \%)$ and
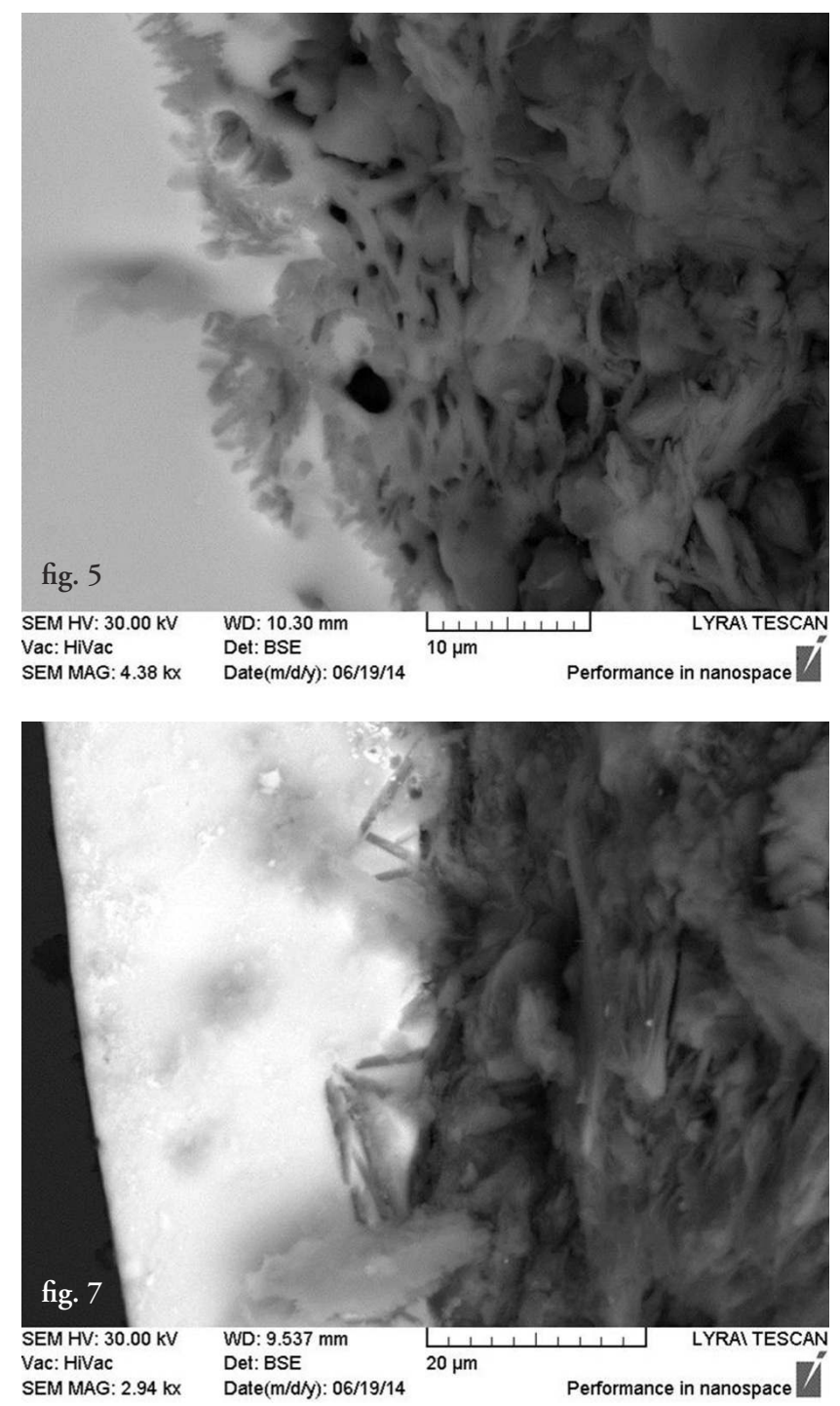

$\mathrm{Fe}_{2} \mathrm{O}_{3}(-2 \%)$ concentrations. Besides the high $\mathrm{CaO}$ concentration, sample Gl-P-10 is also glazed on both sides, which may affect the color of the body.

Some of the ceramic bodies were investigated by SEMEDX. The selected samples were representative of the three described groups: non-calcareous - red color, non-calcareous - grey color and calcareous white color. The obtained images are presented in Fig. 5 to Fig. 7 and demostrate the effect of glazing in reducing and oxidizing conditions on the property of the clay bodies. Fig. 5 presents the SEM image of a red, non-calcareous sample (Gl-P-7), showing vitrification of the ceramic body. The next image (Fig. 6) shows the fine nature of the slip layer of the non-calcareous, grey sample (Gl-P-8). The different structure of the body of sample Gl-P-8 compared to the "one-side" glazed non-calcareous samples is explained with the reducing conditions during

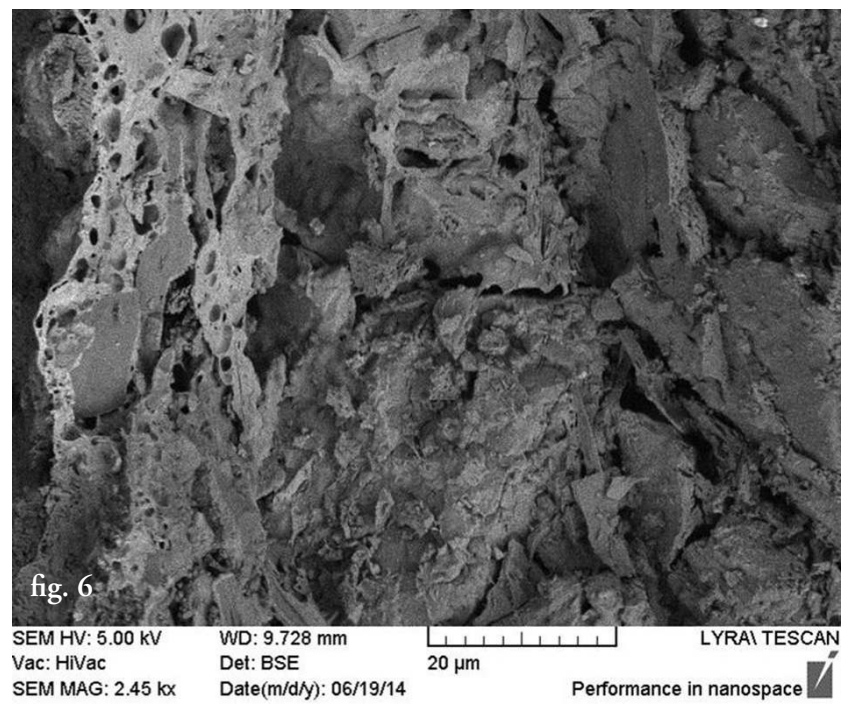

Figure 5: SEM image of the body and part of the glazed layer of sample Gl-P-7.

Figure 5 : Image SEM de la pâte et d'une partie de la couche glaçurée de l'échantillon Gl-P-7.

Figure 6 : SEM image of the body of sample Gl-P-8. Figure 6 : Image SEM de la pâte de l'échantillon Gl-P-8.

Figure 7: SEM image of the body and part of the glazed layer of sample Gl-P-10.

Figure 7 : Image SEM de la pâte et d'une partie de la couche glaçurée de l'échantillon Gl-P-10. 
the firing process. According to Rekecki et al., 2014, the $\mathrm{Fe}^{2+} / \mathrm{Fe}_{\text {total }}$ ratio played a decisive role in the sintering process under a reducing atmosphere. The formed glassy phase, with the presence of $\mathrm{Fe}^{2+}$, attacked the earth-alkali oxides after the carbonate decomposition and more effectively filled smaller pores, resulting in changed microstructural characteristics.

The SEM-image of the calcareous, white ceramic body of the sample Gl-P-10 is shown in Fig. 7. The image shows the presence of bridges between the clay body and the glaze. The dark areas in the glaze are most likely $\mathrm{CaO}$ inclusions.

\section{Chemical composition of the glaze}

Metal concentrations in the glazes are presented in Table 4. In order to check the effect of the ceramic body in the quantification of the glazed layer, calculations for a layered structure were performed.

The calculations assumed that the glaze layers were infinitely thick. For checking the influence of this assumption on the deduced elemental concentrations we performed model calculations for a target composed of a layer of $\mathrm{PbO}$ (with a density of $9.35 \mathrm{~g} / \mathrm{cm}^{3}$ ) sitting on an infinitely thick substrate. In the first step of calculation we generated a ratio of $\mathrm{X}$-rays yields for this structure, and in the second step we calculated the concentrations from these yields for an infinitely thick homogeneous target. First we assumed a layer of $\mathrm{PbO}$ on a substrate of $\mathrm{SiO}_{2}$. The contribution of $\mathrm{Si} \mathrm{K}$ rays was generally quite low on account of lower proton energy and strong $\mathrm{X}$-ray attenuation in the $\mathrm{PbO}$ layer. A significant apparent concentration of $\mathrm{Si}$ in $\mathrm{PbO}$ (higher than 1\%) was

\begin{tabular}{|c|c|c|c|c|c|c|c|c|c|c|c|c|c|}
\hline Sample & color & $\mathrm{Na}_{2} \mathrm{O}$ & $\mathrm{MgO}$ & $\mathrm{Al}_{2} \mathrm{O}_{3}$ & $\mathrm{SiO}_{2}$ & $\mathrm{~K}_{2} \mathrm{O}$ & $\mathrm{CaO}$ & $\mathrm{TiO}_{2}$ & $\mathrm{Cr}_{2} \mathrm{O}_{3}$ & $\mathrm{MnO}$ & $\mathrm{Fe}_{2} \mathrm{O}_{3}$ & $\mathrm{CuO}$ & $\mathrm{PbO}$ \\
\hline Gl-P-1 & white-yellowish & 0.62 & 1.38 & 8.63 & 38.7 & 1.87 & 1.93 & 0.27 & $<0.001$ & 0.030 & 2.55 & 0.03 & 44.0 \\
\hline Gl-P-2 & white-yellowish & 0.85 & 2.37 & 7.97 & 37.3 & 1.37 & 4.91 & 0.28 & $<0.001$ & 0.034 & 2.30 & 0.05 & 42.6 \\
\hline Gl-P-3 & white-yellowish & 0.73 & 1.29 & 7.63 & 41.3 & 0.85 & 2.28 & 0.30 & $<0.001$ & 0.022 & 1.96 & 0.048 & 43.6 \\
\hline Gl-P-4 & white-yellowish & 0.42 & 0.92 & 7.44 & 37.6 & 2.23 & 2.07 & 0.25 & $<0.001$ & 0.019 & 2.04 & 0.07 & 46.9 \\
\hline Gl-P-5.1 & yellow & 0.38 & 0.40 & 6.80 & 34.8 & 0.76 & 1.23 & 0.07 & $<0.001$ & $<0.001$ & 0.50 & 0.21 & 55.2 \\
\hline Gl-P-5.2 & green & 0.54 & 0.94 & 4.80 & 35.4 & 0.62 & 1.53 & 0.17 & $<0.001$ & $<0.001$ & 1.43 & 0.21 & 54.9 \\
\hline Gl-P-6.1 & green & 0.73 & 1.15 & 6.42 & 49.2 & 1.46 & 3.17 & 0.08 & $<0.001$ & $<0.001$ & 1.06 & 4.04 & 33.5 \\
\hline Gl-P-6.2 & brown & 0.44 & 0.80 & 5.50 & 49.3 & 0.88 & 1.75 & 0.07 & $<0.001$ & $<0.001$ & 1.73 & 0.21 & 39.7 \\
\hline Gl-P-6.3 & yellowish & 0.39 & 1.20 & 6.60 & 50.3 & 1.17 & 2.00 & 0.27 & $<0.001$ & $<0.001$ & 0.76 & 0.28 & 37.4 \\
\hline Gl-P-7.1 & yellow & 0.40 & 0.70 & 6.88 & 37.3 & 0.24 & 1.48 & 0.23 & 0.76 & $<0.001$ & 1.09 & $<0.001$ & 51.3 \\
\hline Gl-P-7.2 & brown & 0.54 & 1.41 & 7.04 & 39.4 & 0.29 & 2.39 & 0.35 & 0.49 & $<0.001$ & 2.03 & $<0.001$ & 46.1 \\
\hline Gl-P-8 & brown & 0.62 & 1.44 & 7.54 & 31.6 & 0.59 & 1.11 & 0.35 & $<0.001$ & 0.061 & 2.48 & 0.143 & 54.7 \\
\hline Gl-P-9 & green & 0.29 & 0.65 & 8.20 & 39.5 & 1.31 & 2.31 & 0.15 & $<0.001$ & 0.051 & 0.67 & 2.23 & 44.7 \\
\hline Gl-P-10.1 & brown & 0.38 & 0.81 & 13.0 & 43.6 & 2.57 & 7.63 & 0.55 & $<0.001$ & $<0.001$ & 1.78 & 1.64 & 28.5 \\
\hline Gl-P-10.2 & green & 0.49 & 0.56 & 4.00 & 31.0 & 0.65 & 10.7 & 0.12 & $<0.001$ & 0.035 & 1.87 & 0.55 & 50.6 \\
\hline Gl-P-11 & dark-brown & 0.62 & 0.38 & 3.77 & 34.1 & 0.69 & 13.6 & $<0.001$ & $<0.001$ & 0.063 & 2.52 & $<0.001$ & 44.9 \\
\hline Gl-P-12.1 & black & 0.75 & 0.86 & 8.21 & 29.7 & 0.25 & 1.63 & 0.43 & 0.53 & $<0.001$ & 9.90 & $<0.001$ & 48.6 \\
\hline Gl-P-12.2 & yellow & 0.64 & 0.76 & 8.94 & 32.8 & 0.33 & 1.19 & 0.35 & 0.50 & $<0.001$ & 1.07 & $<0.001$ & 54.1 \\
\hline Gl-P-13.1 & green & 0.28 & 0.89 & 5.47 & 40.6 & 0.64 & 4.39 & 0.17 & $<0.001$ & 0.042 & 1.05 & 1.96 & 44.7 \\
\hline Gl-P-13.2 & brown & 0.28 & 0.67 & 5.34 & 39.5 & 0.59 & 2.54 & 0.12 & $<0.001$ & 2.28 & 1.75 & 0.46 & 46.8 \\
\hline Gl-P-13.3 & yellowish & 0.42 & 0.92 & 4.82 & 41.6 & 0.37 & 2.01 & 0.18 & $<0.001$ & 0.38 & 1.09 & 0.15 & 48.1 \\
\hline Gl-P-14 & yellowish & 0.32 & 0.98 & 4.23 & 43.4 & 0.68 & 4.90 & 0.10 & $<0.001$ & $<0.001$ & 0.48 & 0.12 & 45.1 \\
\hline Gl-P-15 & brown & 0.28 & 0.53 & 4.56 & 31.8 & 0.57 & 0.79 & 0.15 & $<0.001$ & $<0.001$ & 3.65 & 0.05 & 57.8 \\
\hline
\end{tabular}

Table 4: Chemical composition of the glazes (normalized to 100\%) using PIXE-PIGE; the number of the decimal places is related to the precision of the measurements.

Tableau 4: Composition chimique des glaçures (normalisée à $100 \%$ ) obtenue par PIXE-PIGE; le nombre de décimales est liée à la précision des mesures. 
obtained for PbO thicknesses smaller than $3 \mu \mathrm{m}$. We further performed calculation for more penetrative $\mathrm{X}$-rays, selecting a substrate of $\mathrm{Fe}_{2} \mathrm{O}_{3}$. Apparent concentration of $\mathrm{Fe}$ in $\mathrm{PbO}$ smaller than $1 \%$ was obtained for $\mathrm{PbO}$ thicknesses smaller than $10 \mu \mathrm{m}$. However, as the concentration of iron oxide in the pottery body is about an order of magnitude smaller than in pure $\mathrm{Fe}_{2} \mathrm{O}_{3}$ (Table 3), we also determined the thickness of $\mathrm{PbO}$ which yields apparent concentration of iron below $10 \%$; it was $6 \mu \mathrm{m}$. The range of critical $\mathrm{PbO}$ thicknesses is thus smaller than our actual values in the glaze, so the effect of final glaze thickness may be neglected.

Furthermore, the obtained SEM images showed that the actual thickness of the glaze is more than $20 \mu \mathrm{m}$, which ensures that the quantitative results are not influenced by signals that could otherwise emanate from the ceramic body.

The data show that no significant difference may be observed among the metal oxide concentrations depending on the sample dating and type of clay used. The analytical data indicate that these glazes are of the high-lead type. Compared to the eutectic composition, the glaze contains more silica and lower lead oxide, which suggests firing at higher temperature and high viscosity of the mixture, which would hampered the formation of thin layer.

Higher silicon and lower lead oxide concentrations is also visible from the plotted values in Fig. 3 compared to the diagram given by Tite et al. (1998). Similar tendency is observed when comparing the results to literature data for lead glazed potteries from France, England, Serbia and Romania (Walton and Tite, 2010) and Italy (De Benedetto et al., 2004; Walton and Tite, 2010). On the contrary, the present results show lower silicon and higher lead oxide compared to lead glazes composition from Paphos region, Cypros (Charalambous et al., 2010) and similar silicon and lower lead compared to lead-glazed pottery from Paterna, Spain (Molera et al., 1997). This result suggests local production of the studied samples from medieval Bulgaria. The relatively low $\mathrm{Na}_{2} \mathrm{O}$ concentration is indicative that the glaze was not prepared according to the Islamic recipe which is characterized with high concentration of sodium (see e.g. Kuleff, 2012, 350).

The presence of $\mathrm{K}, \mathrm{Al}, \mathrm{Ca}$ and $\mathrm{Fe}$ oxides in the glaze may be partially attributed to the composition of the raw materials used to make the glaze (Molera et al., 1997), but also to the diffusion of the components from the paste to the glaze during the firing. An evidence for the diffusion of $\mathrm{CaO}$ from the body to the glaze is the high concentration of $\mathrm{CaO}$ in the glaze of samples Gl-P-10 and Gl-P-11 (see Fig. 4). The rest of the metal oxides have similar concentrations in the calcareous and non-calcareous samples which leads to the assumption of diffusion processes rather than using another source. The diffusion from the clay to the glaze of $\mathrm{K}, \mathrm{Al}$, $\mathrm{Fe}$ and $\mathrm{Ca}$ has also been assumed by Molera et al. (1997). According to Walton and Tite (2010) when the re-normalized lime content (as described in the results section, see Table 4) in the glaze is higher than in the body, this is probably due to efflorescence to the surface of lime-rich salts in the clay and/or in the hard water used in forming the body. When, the iron oxide content in the glaze is higher than in the body, this is probably due to its addition to the glaze as a colorant. The composition of the present samples shows that $\mathrm{CaO}$ content is higher in the body clay which excludes the efflorescence process. According to the described criteria iron oxide was intentionally added as a colorant in samples Gl-P-10 and Gl-P-11 imported from Byzantium and Gl-P12-1 from medieval Bulgaria.

The colors of studied samples are yellow, green, brown, and black. As can be seen from Figure 2 most of the samples are decorated with more than one color which proves that both iron and copper oxides are intentionally added as colorants. The yellow color of the studied glazes is due to $\mathrm{Fe}^{3+}(-1 \%)$, present most probably as hematite in oxidizing atmosphere.

Elemental analysis of the studied glazes shows that the green color is due to the presence of copper oxide. Although the studied green glazes contain iron oxide at concentrations about $1 \%$ its presence is not responsible for the glaze color. Green color is caused by the presence of $\mathrm{Fe}^{2+}$ under reducing conditions. The green glazed ceramics were certainly fired in oxidizing conditions, confirmed by the red body clay and the combination of green-yellow, green-brown and greenyellow-brown glazes in one sample, which is an indication that copper is in the form of $\mathrm{Cu}^{2+}$, and determines the green color of the glazes (Davis and Stocker, 2013). The brown color is due to the presence of high concentration of $\mathrm{Fe}^{3+}$ $(-2 \%)$, or to the combination of $\mathrm{Fe}^{3+}$ and $\mathrm{Mn}^{3+}$ (samples Gl-P-8, Gl-P-11 and Gl-P-13-2). The black color of the sample Gl-P-12-1 is caused by the intentional addition of $\mathrm{Fe}^{3+}$ at concentration around $10 \%$.

Sample Gl-P-5 deserves more attention. Although the ceramic body is red colored, which is due to the presence of $\mathrm{Fe}^{3+}$ in oxidizing atmosphere, having in mind the low concentration of copper oxide $(0.21 \%)$ in the green glaze, its color is more likely due to high iron oxide concentration $(1.43 \%)$ using reducing condition. The yellowish colored glaze seems to be a second layer, covering the green glaze, applied subsequently in oxidizing environments. The yellowish color could be explained with the presence of $\mathrm{Fe}^{3+}$ in oxidizing atmosphere. Due to environmental erosive factors, the yellowish layer is partially removed (see Fig. 2). 


\section{Method for glaze production}

Table 5 shows the composition of the glazes (sample Nrs 5-15) after subtraction of percentages of $\mathrm{PbO}$ and $\mathrm{CuO}$ and re-normalized to $100 \%$. It has been pointed out that when silica and alumina data points fall on the unity line, the glaze and body composition are essentially the same and, therefore, glazing was by the application of lead oxide by itself. In contrast, when the silica contents are richer in the glaze than in the bodies, and the alumina and lime contents are richer in the bodies than in the glaze, glazing was by the addition of a lead-plus-quartz mixture (Walton and Tite, 2010). In a third variant, proposed by Tite et al., 1998 lead compound and silica are first fired together to produce a frit which was then ground to a powder before being used to prepare the suspension.

In order to distinguish between the two primary methods of glazing, the adjusted glaze composition of $\mathrm{SiO}_{2}, \mathrm{CaO}$,
$\mathrm{Al}_{2} \mathrm{O}_{3}$ and $\mathrm{Fe}_{2} \mathrm{O}_{3}$ were plotted versus the corresponding body composition and are presented in Fig. 8.

The plots, presented in Fig. 8 show that while for lime $\left(\mathrm{R}^{2}=0.92\right)$ and alumina $\left(\mathrm{R}^{2}=0.87\right)$ proportionality between glaze and clay body content is established, for silica the data are poorly correlated $\left(\mathrm{R}^{2}=0.67\right)$.

The concentration of $\mathrm{SiO}_{2}$ and $\mathrm{Al}_{2} \mathrm{O}_{3}$ are equal (Gl-P-8) or higher in the body of both calcareous clay bodies (Gl-P10 and Gl-P-11). The higher lime contents observed in the glazes of these samples could be due to efflorescence to the surface (Walton and Tite, 2010). Therefore, the glazing of this group of samples was performed by the application of lead oxide by itself.

In most of the non-calcareous samples the concentration of silica is higher in the glaze than in the body composition, which could be considered as evidence for glazing by the addition of a lead-plus-quartz mixture. However, this would suggest lower alumina and lime content in the glaze than in

\begin{tabular}{|c|c|c|c|c|c|c|c|c|c|c|}
\hline Sample & $\mathrm{Na}_{2} \mathrm{O}$ & $\mathrm{MgO}$ & $\mathrm{Al}_{2} \mathrm{O}_{3}$ & $\mathrm{SiO}_{2}$ & $\mathrm{~K} \mathrm{O}$ & $\mathrm{CaO}$ & $\mathrm{TiO}_{2}$ & $\mathrm{Cr}_{2} \mathrm{O}_{3}$ & $\mathrm{MnO}_{2}$ & $\mathrm{Fe}_{2} \mathrm{O}_{3}$ \\
\hline Gl-P-1 & 1.11 & 2.47 & 15.4 & 69.1 & 3.34 & 3.45 & 0.48 & $<0.001$ & 0.05 & 4.56 \\
\hline Gl-P-2 & 1.48 & 4.13 & 13.9 & 65.0 & 2.39 & 8.56 & 0.49 & $<0.001$ & 0.06 & 4.01 \\
\hline Gl-P-3 & 1.30 & 2.29 & 13.5 & 73.3 & 1.51 & 4.05 & 0.53 & $<0.001$ & 0.04 & 3.48 \\
\hline Gl-P-4 & 0.79 & 1.74 & 14.0 & 70.9 & 4.21 & 3.90 & 0.47 & $<0.001$ & 0.04 & 3.85 \\
\hline Gl-P-5.1 & 0.85 & 0.89 & 15.2 & 77.7 & 1.70 & 2.75 & 0.16 & $<0.001$ & $<0.001$ & 1.12 \\
\hline Gl-P-5.2 & 1.20 & 2.08 & 10.6 & 78.3 & 1.37 & 3.39 & 0.38 & $<0.001$ & $<0.001$ & 3.16 \\
\hline Gl-P-6.1 & 1.16 & 1.83 & 10.2 & 78.4 & 2.33 & 5.05 & 0.13 & $<0.001$ & $<0.001$ & 1.69 \\
\hline Gl-P-6.2 & 0.74 & 1.35 & 9.28 & 83.2 & 1.49 & 2.95 & 0.12 & $<0.001$ & $<0.001$ & 2.92 \\
\hline Gl-P-6.3 & 0.62 & 1.92 & 10.6 & 80.5 & 1.87 & 3.20 & 0.43 & $<0.001$ & $<0.001$ & 1.22 \\
\hline Gl-P-7.1 & 1.11 & 1.43 & 14.1 & 76.4 & 0.49 & 3.03 & 0.47 & 1.56 & $<0.001$ & 2.23 \\
\hline Gl-P-7.2 & 1.17 & 2.62 & 13.1 & 73.3 & 0.54 & 4.44 & 0.65 & 0.91 & $<0.001$ & 3.77 \\
\hline Gl-P-8 & 0.68 & 3.18 & 16.6 & 69.7 & 1.30 & 2.45 & 0.77 & $<0.001$ & 0.14 & 5.47 \\
\hline Gl-P-9 & 0.55 & 1.22 & 15.4 & 74.4 & 2.47 & 4.35 & 0.28 & $<0.001$ & 0.10 & 1.26 \\
\hline Gl-P-10.1 & 0.54 & 1.16 & 18.6 & 62.3 & 3.67 & 10.9 & 0.79 & $<0.001$ & $<0.001$ & 2.54 \\
\hline Gl-P-10.2 & 1.00 & 1.14 & 8.14 & 63.1 & 1.32 & 21.8 & 0.24 & 0.00 & 0.07 & 3.80 \\
\hline Gl-P-11 & 1.12 & 0.69 & 6.81 & 61.6 & 1.25 & 24.6 & 0.00 & $<0.001$ & 0.11 & 4.55 \\
\hline Gl-P-12.1 & 1.45 & 1.66 & 15.8 & 57.3 & 0.48 & 3.15 & 0.83 & 1.02 & $<0.001$ & 19.1 \\
\hline Gl-P-12.2 & 1.38 & 1.64 & 19.3 & 70.9 & 0.71 & 2.57 & 0.76 & 1.08 & $<0.001$ & 2.31 \\
\hline Gl-P-13.1 & 0.52 & 1.67 & 10.2 & 76.0 & 1.20 & 8.22 & 0.32 & $<0.001$ & 0.08 & 1.97 \\
\hline Gl-P-13.2 & 0.54 & 1.29 & 10.3 & 76.1 & 1.14 & 4.89 & 0.23 & $<0.001$ & 4.40 & 3.37 \\
\hline Gl-P-13.3 & 0.81 & 1.78 & 9.31 & 80.4 & 0.71 & 3.88 & 0.35 & $<0.001$ & 0.73 & 2.11 \\
\hline Gl-P-14 & 0.58 & 1.78 & 7.70 & 79.0 & 1.24 & 8.92 & 0.18 & $<0.001$ & $<0.001$ & 0.87 \\
\hline Gl-P-15 & 0.66 & 1.25 & 10.8 & 75.3 & 1.35 & 1.87 & 0.35 & $<0.001$ & $<0.001$ & 8.64 \\
\hline
\end{tabular}

Table 5: Chemical composition of the glazes - renormalized to $100 \%$ after subtraction of percentages of $\mathrm{PbO}$ and $\mathrm{CuO}$ contents. Tableau 5: Composition chimique des glaçures renormalisée à $100 \%$ après la soustraction des teneurs en $\mathrm{PbO}$ (en pourcentage) et CuO (en pourcentage). 

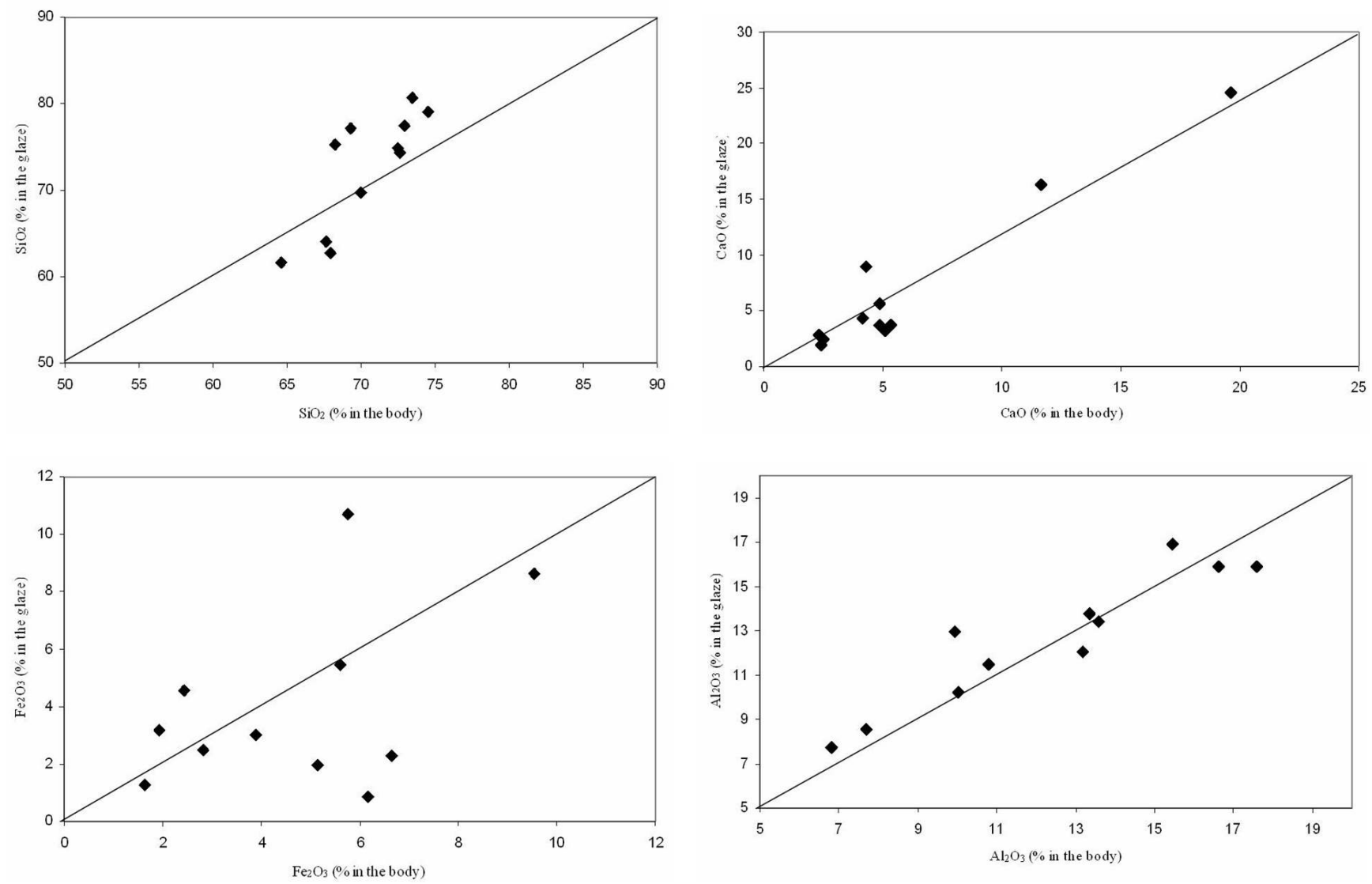

Figure 8: Two-dimensional diagrams of the renormalized glaze composition of $\mathrm{SiO}_{2}, \mathrm{CaO}, \mathrm{Al}_{2} \mathrm{O}_{3}$ and $\mathrm{Fe}_{2} \mathrm{O}_{3}$ vs. the corresponding body composition.

Figure 8: Diagrammes binaires des compositions renormalisées de $\mathrm{SiO}, \mathrm{CaO}, \mathrm{Al}_{2} \mathrm{O}_{3}$ et $\mathrm{Fe}_{2} \mathrm{O}_{3}$ dans les glaçures et les pâtes correspondantes.

the body (Walton and Tite, 2010). The close concentrations of alumina and calcium in the body and the glaze in some of the samples (see e.g. Gl-P-6.1, Gl-P-7-2, Gl-P-9; Gl-P-12.2, Gl-P-13.2) contradict this assumption.

It might be also assumed that silica was added to the lead compound to prepare the suspension (Tite et al., 1998).

Though, the presence of samples, with different colored glazes, in which the concentration of silica is higher (Gl-P7.1) and comparable (Gl-P-7.2) or lower (Gl-P-12.1) and higher (Gl-P-12.2) than the corresponding concentration in the clay bodies further confirms that neither quartz nor silica were added to the glaze. Thus, it can be concluded that both the calcareous and the non-calcareous samples were glazed using lead oxide by itself.

The plot, presenting the adjusted glaze composition of $\mathrm{Fe}_{2} \mathrm{O}_{3}$ versus the corresponding body composition showed rather scattered distribution of the respective points $\left(\mathrm{R}^{2}=0.22\right)$ which may be due to the intentional addition of iron oxide as coloring agent.
Because of the limited number of samples analyzed in the present work and according only to the elemental composition, a precise geographic location of the raw material sources is not possible to define. However, it should be pointed out that during archeological excavations medieval kilns for pottery production were discovered in Drastar (Angelova and Koleva, 2005; Koleva, 2008) which is evidence for the local production of the studied glazed potteries. Production of lead-glazed pottery using non-calcareous clay in combination with lead oxide by itself has been established by Walton and Tite (2010) for samples produced in the Balkans (Serbia and Romania) from the $1^{\text {st }}$ to the $4^{\text {th }}$ centuries AD. Futhermore, lead-isotope analysis of lead-glazed pottery found in Eastern Europe, proved that the lead for the glaze was obtained using ores from Bulgaria (i.e. the Rhodopi mountains) and it was concluded that the pottery was produced locally within the Danubian region (Iliev, 2006; Walton and Tite, 2010). 


\section{Conclusion}

The study of 15 medieval lead-glazed ceramics from Drastar, Bulgaria provides significant information on the chemical composition and the techniques used for their production. In particular the present study has shown that both calcareous and non-calcareous clay bodies were used for pottery production. The calcareous clay bodies have white color due to the high lime content. The majority of the non-calcareous clay bodies are red colored, determined by the high iron oxide concentration in the form of hematite. Despite the presence of high concentration of iron oxide, two of the samples from this group have grey (Gl-P-8) and white (GlP-9) colored clay bodies. Both of them are entirely glazed which creates a reducing atmosphere inside the clay during the firing process and the presence of hercynite and $\mathrm{Fe}^{2+}$.

Concerning the glazes, the yellow color is due to the presence of $\mathrm{Fe}^{3+}$, the brown to $\mathrm{Fe}^{3+}$ in higher concentration or to the combination of $\mathrm{Fe}^{3+}$ and $\mathrm{Mn}^{3+}$ and the green color to $\mathrm{Cu}^{2+}$.

Further studies on more samples excavated in Bulgaria are needed to extend the knowledge of glaze pottery production in Bulgaria.

\section{Acknowledgements}

The authors would like to express gratitude to Assist. Prof. Dr. Rumyana Koleva for the valuable comments and discussion and also to Assist. Prof. Dr. Chavdar Kirilov from the Faculty of History at the University of Sofia for providing the glazed pottery samples. One of the authors (Valentina Lyubomirova) is thankful to the IAEA-Vienna for funding the fellowship at the Jožef Stefan Institute, University of Ljubljana, Slovenia.

\section{Bibliography}

Angelova S., 1988. Archaeological study of medieval Drastar. Results and Prespectives. In Durostorum - Drastar, Silistra, 90 years museum work, 32-53 (in Bulg.).

Angelova S., Koleva R., 2005. Kilns for fire of life pottery from Drastar. Studia Archaeologica Universitatis Serdicensis. Supplementum IV (2005), Stephanos Archaeologicos, In honorem Professoris Ludmili Getov, 10-14 (in Bulg.).

Charalambous A.C., Sakalis A.J., Kantiranis N.A., Papadopoulou L.C., Tsirliganis N.C., Stratis J.A., 2010. Cypriot Byzantine glazed pottery: Study of the Paphos workshops. Archaeometry, 52, (4): 628-643.
Davis J.L., Stocker S.R., 2013. The Medieval deposit from the northeast gateway at the palace of Nestor. Hesperia, 82: 673731.

De Benedetto G. E., Acquafredda P., Masieri M., Quarta G., Sabbatini L., Zambonin P.G., Tite M., Walton M., 2004. Investigation of Roman lead glaze from Canosa: Results of chemical analyses. Archaeometry, 46, (4): 615-624.

Djingova R., Kuleff I., 1992. An archaeometric study of medieval glass from the first Bulgarian capital, Pliska (ninth to tenth century AD). Archaeometry, 34(1): 53-61.

Harbottle G., 1976. Activation Analysis in Archaeology. In G.W.A. Newton (ed.). Radiochemistry: a specialist periodical report, The Chemical Society, London, 33-72.

Hurst D, Freestone I., 1996. Lead glazing technique from a medieval kiln site at Hanley Swan, Worcestershire. Medieval Ceramics, 20: 13-18

ILIEv I., 2006. Archaeometric investigations of metal finds from Bulgaria using INAA, ED-XRF and ICP-MS, PhD thesis, University of Sofia “St. Kliment Ohridski”, Sofia, Bulgaria (in Bulg.).

Ivanova Ju., Djingova R., Kuleff I., 1998. Determination of some heavy and toxic elements in plants and soils with ED-XRF using americium-241 excitation source. Journal of Radioanalytical and Nuclear Chemistry, 238, (1-2): 29-32.

Kleinmann B., 1991. Cobalt-pigments in the early Islamic blue glazes and the reconstruction of the way of their manufacture. In E. Pernicka, G. Wagner (ed.). Proceedings of the $27^{\text {th }}$ International Symposium on Archaeometry. Archaeometry-90, Birkhäuser Verlag, Basel, Heidelberg, 1990, 327-336.

Koleva R., 2008. Data on the sgraffito ware production of in the medieval city of Drastar. Supplementum V, Stephanos Archaeologicos, In honorem Professoris Stefka Angelova, 547564 (in Bulg.).

Koleva R., 2009. Medieval glazed ceramics from Drastar. EURIKA, In honorem Ludmilae Donchevae-Petkovae, 275-289.

Koleva R., 2015. The Population of the Medieval Settlement near the Village of Zlatna livada, Chirpan Region, Bulgaria (Based on Pottery Studies). Bulgarian e-Journal of Archaeology, 5: 37-52.

Kuleff I., 2012. Archaeometry, “St. Kliment Ohridski”University Publishing House, Sofia.

Kuleff I., Djingova R., 1998. Mean Concentration of Elements Determined in Ohio Red Clay. Journal of Radioanalytical and Nuclear Chemistry, 237, (1-2): 3-6.

Mancheva O., 1986. Medieval ceramic ware from the fond of Regional historical museum - Silistra, Dobrudzha, 3: 100-109.

Molera J., Vendrell-Saz M., García-Valés M., Prudell T., 1997. Technology and color development of hispanomoresque lead-glazed pottery, Archaeometry, 39, (1): 23-39. 
Rekecki R., Ranogajec J., Oszkó A., Kuzmann E., 2014. Effects of firing conditions on the properties of calcareous clay roofing tiles. Journal of Materials in Civil Engineering, 26, (1): $175-183$.

Tite M., Freestone I., Mason R., Molera J., Vendrell-Saz M., Wood N., 1998. Lead glazes in antiquity - Methods of production and reasons for use. Archaeometry, 40, (2): 241-260.

Wakamatsu M., Takeuchi N., Ishida Sh., 1987. Effect of furnace atmosphere on color of iron glaze. Journal of Non-Crystalline Solids, 95/96: 733-740.
Walton M., Tite M. 2010. Production technology of Roman lead-glazed pottery and its continuance into late antiquity. Archaeometry, 52, (5): 733-759.

Wolf S., Stos S., Mason R., Tite M., 2003. Lead isotope analyses of Islamic pottery glazes from Fustat, Egypt. Archaeometry, 45, (3): 405-420.

Yoleva A., Djambazov S., Djambazov P., 2015. Study of medieval ceramics excavated at the monastery of Karaachteke (Varna, Bulgaria), Journal of Chemical Technology and Metallurgy, 50 (4): $531-536$ 